\title{
GROWTH PERFORMANCE AND CARCASS QUALITY ASSESSMENT OF PUREBRED AND CROSSBRED ROMANOV LAMBS
}

\author{
Nawzad. M. Aziz ${ }^{1}$ \\ Dvalishvili. V. G. ${ }^{2}$
}

${ }^{1}$ Department of Animal Resources, College of Agriculture Engineering Sciences,

Salahaddin University-Erbil, Kurdistan Region, Iraq.

${ }^{2}$ Department of Breeding and Nutrition, All-Russian Research Institute of

Livestock, Academician L. K. Ernst, Moscow, Russia.

Email:nawzad.aziz@su.edu.krd

\begin{abstract}
The present study aimed to examine the growth performance and characteristics of carcass quality of purebred and crossbred Romanov male lambs (3/4 Romanov $\times 1 / 4$ Edilbai). A total of 40 male lambs ( 3 months aged) from two different genotypes (20 of each genotype) were used. Lambs were reared under the same management system for 8 months of age. The growth and characteristics of carcass as hot and cold weight of carcass, dressing percentage and carcass composition were determined for each group of lambs. The results indicated a significant difference $(\mathrm{P} \leq 0.05)$ in growth traits between purebred and crossbred Romanov lambs. The crossbred Romanov lambs had significantly higher final body weight and weight gain per day compared to purebred Romanov lambs. Moreover, a significant increase was recorded for all carcass traits in Romanov crossbred lambs compared with purebred Romanov lambs. Due to high production and carcass traits, Romanov crossbred lambs can be used for the production of meat purposes. However, further investigations of these crossbred lambs need to be evaluated before any recommendation is given.
\end{abstract}

Keywords: carcass traits, crossbreeding, growth performance, sheep.

Received: 22 / 9 /2020, Accepted: $11 / 10 / 2020$

\section{INTRODUCTION}

In Russia, a significant subjects dealing with sheep production is breeding of sheep. The major objective of all breeding programs aimed to organize good profitable sheep flocks which have been identified as a significant agriculture area providing the human with meat and milk as well as essential raw materials (wool, skin) which are economically and strategically important for Russia (Dvalishvili et al., 2015).

Romanov, the predominant sheep in Russia, one of the economically most important profitable sheep breeds characterized by several desirable traits such as this sheep genetically distinct breeds because (1) the breeds carry pure genes; (2) the breeds do not produce from any crosses and (3) the breeds are an extremely reproductive and productive performance with high yielding lamb, as a Romanov ewe able to produce seven live and healthful lambs in a single litter (Korkmaz and Emsen, 2016). Romanov sheep, however, cannot meet the requirements of either breeders or customers because their lambs are poor in performance and carcass yield (Khaldari and Ghiasi, 2018; Zapasnikienè, and Nainienè, 2012). To overcome 
such problems, Romanov sheep need crossing strategies with breeds of sheep which have high growth rate and meat productivity.

Edilbai sheep breed is originated in southwestern Asia and classified as a meat-fat breed. They characterized by a strong constitution, high feed conversion efficiency and meat productivity, great hardiness to adverse conditions of management so they can be reared in harsh deserts and semi-desert areas (Fathala et al., 2014). This sheep breed has spread to many countries in the world of which Kazakhstan, Uzbekistan, Kyrgyzstan, Tajikistan, Turkmenistan, then China, Afghanistan, Iran, Turkey, the countries of the Arabian Peninsula and in Africa. In Russia, at the last 20 years, there has been some interest in the meat-fat Edilbai breed, which has a high maturity, good meat quality and excellent adaptation to the adverse circumstances of management and feeding. Therefore, the current study was carried out to assess growth performance and quality of carcass in crossbred (3/4 Romanov: 1/4 Edilbai) and purebred Romanov male lambs.

\section{Animals and experimental design}

\section{MATERIAIS AND METHODS}

Forty Romanov male lambs ( 3 months aged) with an average body weight of $22.5 \pm 1.17 \mathrm{~kg}$ reared under same management system and obtained from All-Union Scientific Research Institute of Animals (VIZH), Moscow, Russia were used in the study. Based on their genotype, animals were assigned into two groups of twenty animals of pure Romanov lambs and twenty crossbred Romanov lambs of Romanov ewes intermarriage with Edible ram (3/4 Romanov $\times 1 / 4$ Edilbai). Lambs were housed into two individual and good ventilation pens bedded with wood shavings within the same house after they identified using plastic ear tags. During the 80 days of the treatment period, two balanced diets were formulated for the first (3-6 months) and second (6-8 months) halves of the period of fattening. Feed composition (Table 1) was prepared for both fattening periods to meet the requirements of all nutrients for lambs. The diet was involved two main components which were concentrates and green fodders (Alfalfa). The concentrate ration consisted of wheat, barley as well as oats as a protein source and salt and mineral premix as dispenser and mineral additives.

\section{Growth performance}

Final body weights for both genotypes of lambs were recorded at the start of the experiment while fasting and monthly thereafter until the end of the experimental period. Additionally, the average daily weight gain was recorded basis on the rate of weight gain per day over a specified period.

\section{Slaughtering procedures and carcass measurements}

At the end of the experiment, the lambs were weighed and slaughtered to determine slaughtering and carcass characteristics. Upon slaughter, hot carcass weights were weighed $(\mathrm{HCW})$ after removal of the head, skin, fore and hind feet, tail, kidney, kidney fat and the visceral organs. After carcasses were chilled at $4{ }^{\circ} \mathrm{C}$ for $24 \mathrm{~h}$, the cold carcass weights were obtained (CCW). The difference between hot and cold carcass weight was estimated as percentage of chilling loss. Dressing percentage was calculated by dividing the $\mathrm{HCW}$ or $\mathrm{CCW}$ by the slaughter weight of 
the animal and expressing the result as a percentage. Carcass were divided into two equal right and left sides through the center of the backbone. The neck, shoulder, breast, flank, loin and leg cuts were separated from right part of the carcass and each cut was dissected into lean, fat and bone on the basis of the procedure reported by Khaldari and Ghiasi (2018). The fat that surrounded the intestine and abdomen were considered the abdominal fat, while the fat surrounded kidney and pelvic were considered internal fat (Fathala et al., 2014).

Table (1): Composition and nutrient content of diets for lambs from 3 to 8 months of age (\%, as fed-basis)

\begin{tabular}{|l|c|c|c|c|}
\hline \multirow{2}{*}{ Indicator } & Romanov & $\begin{array}{c}\text { Romanovx } \\
\text { Edilbai }\end{array}$ & Romanov & $\begin{array}{c}\text { Romanov } \\
\times \text { Edilbai }\end{array}$ \\
\cline { 2 - 5 } & \multicolumn{4}{|c|}{ Age, month } \\
\cline { 2 - 5 } & \multicolumn{3}{|c|}{$3-6$} & \multicolumn{2}{c|}{$6-8$} \\
\hline Green fodders, kg /head/day & 2.77 & 3.06 & 3.60 & 3.85 \\
\hline Concentrates, g /head/day & 550 & 550 & 750 & 750 \\
\hline The chemical composition of diet, DM basis \\
\hline Dry Matter, kg & 1.47 & 1.57 & 1.89 & 1.98 \\
\hline Energy metabolism, MJ & 16.33 & 17.44 & 19.62 & 20.55 \\
\hline Crude Protein, g & 222 & 236 & 283 & 296 \\
\hline Digestible crude protein, g & 163 & 174 & 196 & 206 \\
\hline Crude fat, g & 56 & 60 & 72 & 76 \\
\hline Crude fiber, g & 219 & 240 & 287 & 305 \\
\hline Nitrogen-free extract, g & 712 & 757 & 943 & 983 \\
\hline Calcium, g & 8.4 & 9.0 & 10.9 & 11.7 \\
\hline Phosphorus, g & 5.8 & 6.2 & 10.2 & 10.9 \\
\hline Sulfur, g & 4.7 & 5.0 & 6.6 & 7.1 \\
\hline Carotene, mg & 85 & 89 & 120 & 128 \\
\hline Digestible crude protein, g & 1.63 & 1.74 & 1.96 & 2.06 \\
\hline
\end{tabular}

${ }^{1}$ Diets were formulated using FeedLIVE software (FeedLIVE 1.52, Thailand).

\section{Statistical analyses}

The experiment was carried out according to the completely randomized design and data obtained for all parameters were analyzed by the generalized linear model (GLM) procedure of Anonymous (2003). The differences among means were tested with independent sample T-test at level of 0.05. Characteristics were expressed as mean \pm standard errors. Differences among means were tested using Duncan test (Steel and Torrie, 1984).

\section{Growth performance}

\section{RESUITS AND DISCUSSION}

The results of growth performance of lambs such as average daily gain and body weight of the two genotypes are presented in Figure 1 . Differences $(\mathrm{P} \leq 0.05)$ were evident between the average daily gain and body weight of the purebred and crossbred Romanov lambs because the crossbreds lambs had better daily weight 
gain and final body weight of about 18 and $13 \%$ in comparison with purebred lambs, respectively. The result of crossing the purebred Romanov lambs were showed enhancement of the growth performance. In Russia federation, growth rate performance of the purebred lambs reflected as the main issue meeting purebreeding sheep expansion, especially for Romanov breed. This finding is in tandem with those of Khaldari and Ghiasi (2018) and Dvalishvili et al., (2015) who reported an increase daily gain for lambs from Romanov crossbreed compared to purebred Romanov lambs. The data obtained by Dvalishvili et al., (2015) and Fathala et al., (2014) showed that crossbred Romanov lambs significantly improve the body weight than that of the purebred Romanov lambs. It seems that the superiority of crossbred lambs in relation to purebred lambs in terms of body weight gain is caused by the effect of hybrid vigor (Khaldari and Ghiasi, 2018). In numerous countries especially where lamb meat production is of primary importance, commercial crossbreeding programs have been widely applied to produce efficient lambs for slaughter purposes. This can be got by enhancing daily weight gain during the fattening period by means of appropriate crossbreeding programs (Esmailizadeh et al., 2012).

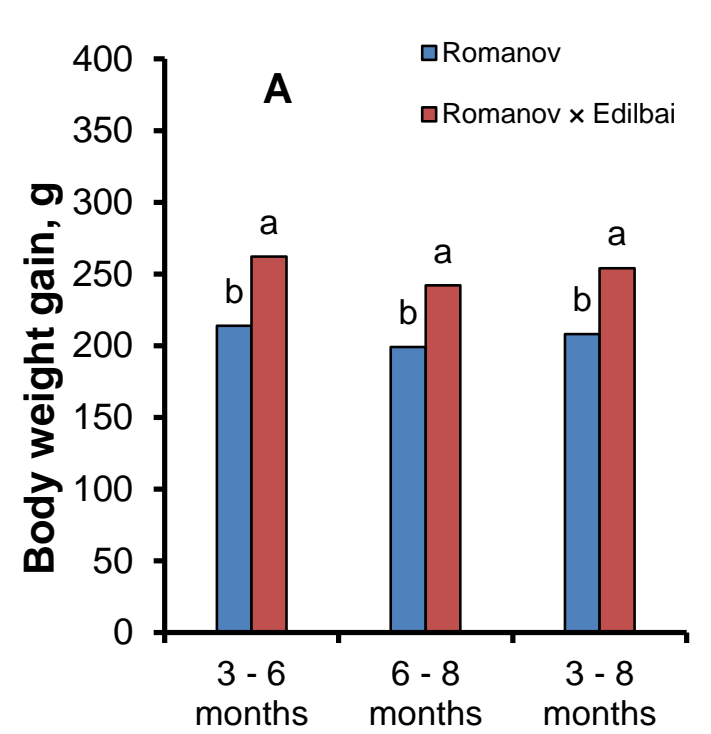

Age

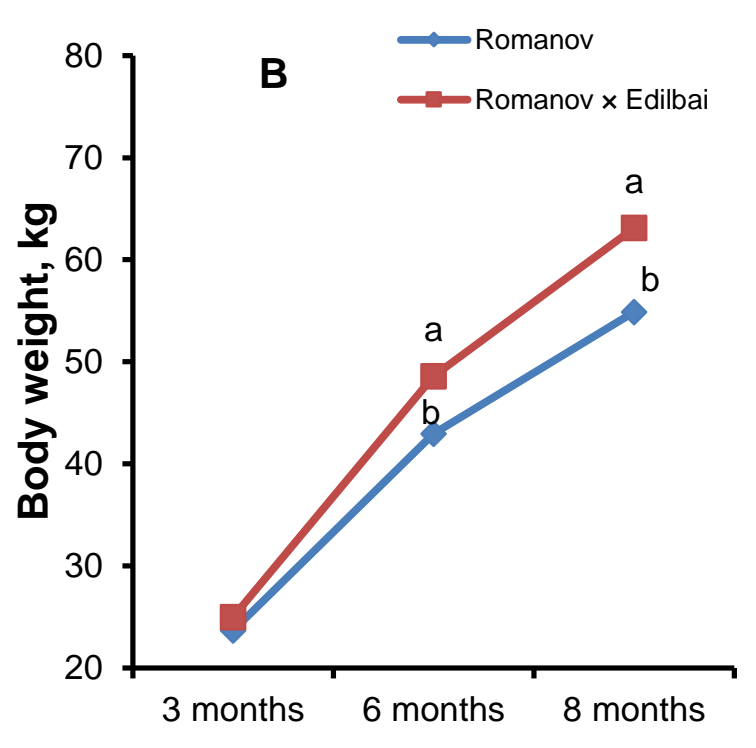

Age

Figure (1): Daily average growth (A) and body weight (B) of purebred and crossbred Romanov lambs.

${ }^{a, b}$ Means are significantly different at $\mathrm{p} \leq 0.05$.

\section{Carcass quality}

Carcass is the body of an animals butchered for meat. The term is used following dressing that is, the removal of various parts from the body after butchering (Adzitey, 2011; Kadim et al., 2008). In lambs, the characteristics of carcass including hot carcass weight, cold carcass weight and dressing percentage are determined by many factors such as breed, slaughtering weight, feed and weaning age (Ekiz et al., 2012). An indicator for significant efficacy of lambs and 
their ability for meat production is improvement carcass yields characteristics. The quality characteristics of carcass of purebred and crossbred Romanov lambs are shown Table 2. The mean values for traits such as hot carcass weight, cold carcass weight and carcass yield or dressing percentage were significantly differences $(\mathrm{p} \leq 0.05)$ between lambs groups and the crossbred Romanov lambs had the higher values than purebred ones. The difference between the purebred and crossbred Romanov lambs could be due to the variance of slaughter body weight (Table 2) that is affected by genetic factors. According to Khaldari and Ghiasi (2018), the superiority of the Romanov crossbred lambs is likely due to the genetic structure of these breeds for body size and body weight. The abdominal fat and the kidney and pelvic fat as well as chilling loss (Table 2$)$ were not influenced $(p \leq 0.05)$ by genotype. This finding is consistent with those of Fathala et al., (2014) who found difference $(p \leq 0.05)$ between genotypes of sheep (Romanov lambs and crossbred lambs Edilbai $\times$ Romanov) on quality characteristics of carcass such as carcass weight and dressing percentage. Also, Dvalishvili et al. (2015) reported that crossbred Romanov lambs had higher lamb carcass weight and carcass yield than purebred ones. Santos-Silva et al. (2002) stated that slaughter weight and carcass weight of lambs were significantly affected by genotype of the lambs.

Table (2): Carcass traits of purebred and crossbred Romanov lambs.

\begin{tabular}{|l|c|c|}
\hline \multirow{2}{*}{ Indicator } & \multicolumn{2}{|c|}{ Breed group } \\
\cline { 2 - 3 } & Romanov & Romanov $\times$ Edilbai \\
\hline Pre-slaughter weight, $\mathrm{kg}$ & $52.76 \pm 0.37^{\mathrm{b}}$ & $61.88 \pm 0.54^{\mathrm{a}}$ \\
\hline Hot carcass weight*, $\mathrm{kg}^{\mathrm{a}}$ & $26.55 \pm 0.31^{\mathrm{b}}$ & $32.60 \pm 0.42^{\mathrm{a}}$ \\
\hline Cold carcass weight*, $\mathrm{kg}^{\mathrm{b}}$ & $25.21 \pm 0.31^{\mathrm{b}}$ & $30.98 \pm 0.42^{\mathrm{a}}$ \\
\hline Chilling loss, \% $^{\mathrm{b}} \%$ & $1.34 \pm 0.08$ & $52.86 \pm 0.07$ \\
\hline Dressing percentage $^{1}$ & $49.64 \pm 0.29^{\mathrm{b}}$ & $50.07 \pm 0.37^{\mathrm{a}}$ \\
\hline Dressing percentage $^{\mathrm{a}}$ & $47.78 \pm 0.22^{\mathrm{b}}$ & $1.97 \pm 0.12$ \\
\hline Abdominal fat, kg & $1.34 \pm 0.07$ & $0.18 \pm 0.07$ \\
\hline Kidney and pelvic fat, $\mathrm{kg}$ & $0.15 \pm 0.04$ & $0.42 \pm 0.05$ \\
\hline Fat tail, kg & - & \\
\hline
\end{tabular}

${ }_{1}^{1}$ is calculated as (hot carcass weight / slaughter weight) $\times 100$

${ }^{2}$ is calculated as (cold carcass weight / slaughter weight) $\times 100$

${ }^{\mathrm{a}, \mathrm{b}}$ Means with different letters are significantly different at $\mathrm{p} \leq 0.05$.

The measurements of the lean and fat content are used to determine carcass value (Knight et al., 2020; Anderson et al., 2015). The carcass obtained from crossbred lambs had significantly more tissue of lean and fat. Nevertheless, the values of bone obtained from purebred or crossbred Romanov carcass lambs were not significantly different $(\mathrm{p}>0.05)$ (Table 3 ). Consequently, the ratio of meat to bone was more by $16 \%$. The carcass values are affected by the ratio of muscle: bone at a particular fat level. Obviously, a higher ratio is preferable as it equates to more saleable lean meat as well as highest carcass conformation (Irshad et al., 2013). The results could be due to the effect of crossbreeding upon the meat production of the lambs. Crossbreeding improved carcass traits via reducing the body fat (Dvalishvili 
et al., 2015). The improvement in lean value through crossing strategies is in tandem with the findings of Dvalishvili et al., (2015) and Fathala et al., (2014).

Table (3): Carcass components of purebred and crossbred Romanov lambs.

\begin{tabular}{|c|c|c|}
\hline \multirow{2}{*}{ Indicator } & \multicolumn{2}{|c|}{ Breed group } \\
\cline { 2 - 3 } & Romanov & Romanov $\times$ Edilbai \\
\hline Lean, $\mathrm{kg}$ & $17.20 \pm 0.22^{\mathrm{b}}$ & $21.67 \pm 0.36^{\mathrm{a}}$ \\
\hline Fat, kg & $3.31 \pm 0.10^{\mathrm{b}}$ & $4.87 \pm 0.12^{\mathrm{a}}$ \\
\hline Bone, $\mathrm{kg}$ & $4.55 \pm 0.14$ & $4.26 \pm 0.22$ \\
\hline Other tissues, kg & $0.15 \pm 0.04$ & $0.18 \pm 0.07$ \\
\hline Lean / bone ratio & $3.78 \pm 0.09^{\mathrm{b}}$ & $5.08 \pm 0.19^{\mathrm{a}}$ \\
\hline
\end{tabular}

${ }_{\mathrm{a}, \mathrm{b}}$ Means with different letters are significantly different at $\mathrm{p} \leq 0.05$.

\section{CONCLUSIONS}

The results of the current study indicate that the Romanov crossbred lambs had higher $(\mathrm{p} \leq 0.05)$ growth performance and characteristics of carcass quality than purebred Romanov. With these results, Romanov crossbred lambs may be chosen for purposes of meat production. On the other hand, prior any recommendation may be given; more investigation should be carried out to decide whether using Romanov crossbred lambs as a crossbreeding commercial line or a start for developing a new genotype.

\section{DISCLOSURE STATEMENT}

The authors declare that they have no conflicts of interest.

\section{تقييم اداء النمو وصفات الذبيحة لحملان الرومانوف النقية والمضربة}

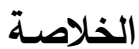

كان الهدف من الدراسة الحالية هو تقييم الأداء الإنتاجي والخصائص النوعية لذبيحة حملان رومانوف النقية

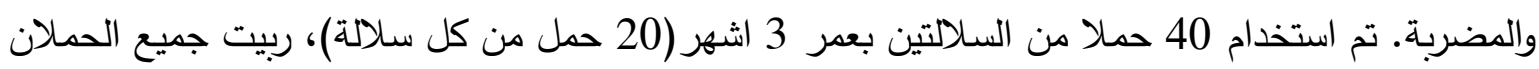

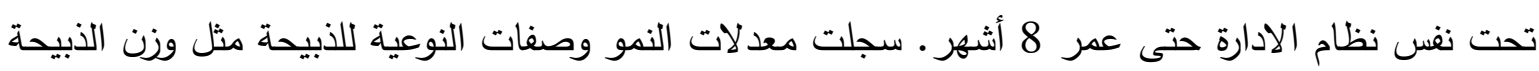
ونسبة التصافي اضافة الى تركيب الذبيحة لكل مجموعة من الحملان. أشارت نتائج الدراسة إلى أن حملان

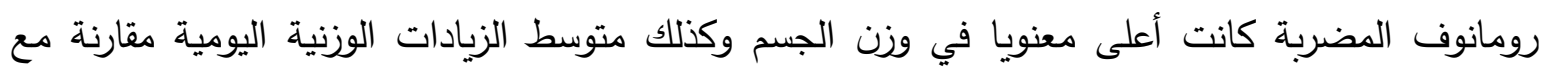

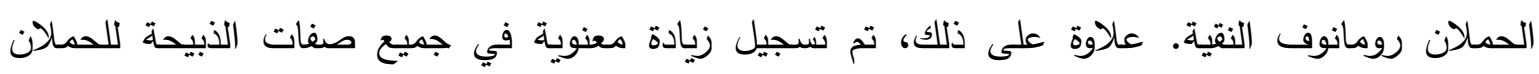

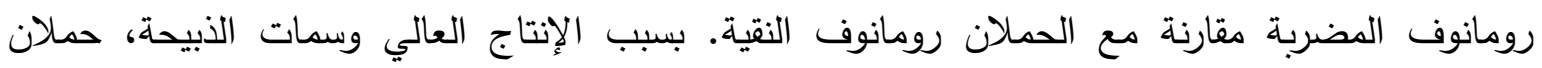

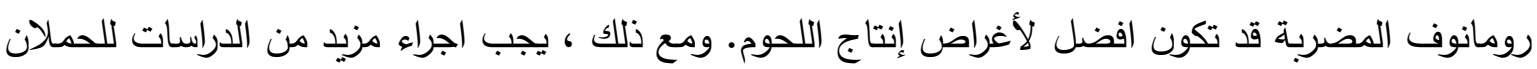
رومانوف المضربة قبل اعطاء اي توصية.

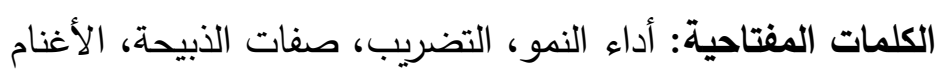

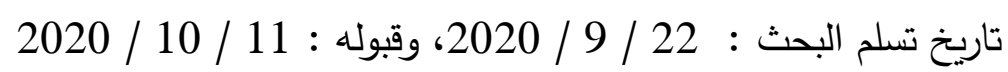




\section{REFERENCES}

Adzitey, F. (2011). Effect of pre-slaughter animal handling on carcass and meat quality. International Food Research Journal. 18(2), 485-491.

Anderson, F.; D. W. Pethick and G. E. Gardner (2015). The correlation of intramuscular fat content between muscles of the lamb carcass and the use of computed tomography to predict intramuscular fat percentage in lambs. Animal. 9(7), 1239-1249.

Anonymous (2003). Statistical Analytical System. SAS Userk Guide: Statistics. SAS Institute Inc., Carry, N.C, USA.

Dvalishvili, V. G.; M. M.Fathala; I. S. Vinogradov and A. Dawod (2015). Influence of crossbreeding Romanov ewes with crossbred Argali Romanov rams on male progeny performance and carcass traits. Journal of Veterinary Science and Technology. 6(275), 2-7.

Ekiz, B.; A. Yilmaz; M. Ozcan and O. Kocak, (2012). Effect of production system on carcass measurements and meat quality of Kivircik lambs. Meat Science. 90(2), 465-471.

Esmailizadeh, Ali K., Mostafa Nemati, and Mortaza S. Mokhtari (2012). Fattening performance of purebred and crossbred lambs from fat-tailed Kurdi ewes mated to four Iranian native ram breeds. Tropical animal health and production. 44(2), 217-223.

Fathala, M. M.; V. G. Dvalishvili and P. E. Loptev (2014). Effect of crossbreeding Romanov ewes with Edilbai rams on growth performance, some blood parameters and carcass traits. Egyptian Journal of Sheep and Goat Sciences. 65(1798), 1.

Irshad, A.; G. Kandeepan; S. Kumar; K. A. Ashish; M. R. Vishnuraj and V. Shukla (2013). Factors influencing carcass composition of livestock: A review. Journal of Animal Production Advances. 3(5), 177-186.

Kadim, I. T.; O. Mahgoub and R. W. Purchas (2008). A review of the growth, and of the carcass and meat quality characteristics of the one-humped camel (Camelus dromedaries). Meat Science. 80(3), 555-569.

Khaldari, M. and H. Ghiasi (2018). Effect of crossbreeding on growth, feed efficiency, carcass characteristics and sensory traits of lambs from LoriBakhtiari and Romanov breeds. Livestock Science. 214, 18-24.

Knight, M. I.; K. L. Butler; N. P. Linden; V. F. Burnett; A. J.Ball; M. B. McDonagh and R. Behrendt (2020). Understanding the impact of sire lean meat yield breeding value on carcass composition, meat quality, nutrient and mineral content of Australian lamb. Meat Science. https://doi.org/10.1016/j.meatsci.2020.108236

Korkmaz, M. K.; and E. Emsen (2016). Growth and reproductive traits of purebred and crossbred Romanov lambs in Eastern Anatolia. Animal Reproduction. 13(1), 3-6.

Santos-Silva, J.; I. A. Mendes; and R. J. B. Bessa (2002). The effect of genotype, feeding system and slaughter weight on the quality of light lambs: 1 . Growth, carcass composition and meat quality. Livestock Production Science. 76(12), 17-25. 
Mesopotamia J. of Agric.

ISSN: 2224 - 9796 (Online)

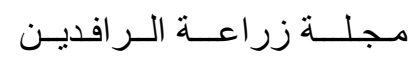

Vol. (48) No. (4) 2020

ISSN: 1815 - 316 X (Print) 2020 المجلد (48) العدد (4)

Steel, R. G. D.; and J. H. Torrie, (1984) Principles and Procedures of Statistics: A Biometrical Approach. $2^{\text {nd }}$ McGraw Hill Book Co., Singapore.

Zapasnikienė, B. and R. Nainienè (2012). The effects of crossbreeding Romanov ewes with Wiltshire Horn rams on ewe fertility and progeny performance. Veterinarija Ir Zootechnika. 57, 79-84. 